\title{
ThermoWood Metoduna Göre Isıl İşlem Görmüş ve Su-Bazlı Vernikler Uygulanmış Ahşap Malzemeler Üzerinde Hızlandırılmış UV Yaşlandırma Etkisine Karşı Yüzey Pürüzlülüğünün Belirlenmesi
}

\author{
Determination of Surface Roughness Against the Effect of Accelerated UV Aging on Water- \\ Based Varnish Applied and Heat treated Wood Materials According to ThermoWood \\ Method
}

\author{
Ümit AYATA ${ }^{1, a}$, Nevzat CAKICIER*2,b \\ ${ }^{1}$ Atatürk Üniversitesi, Oltu Meslek Yüksekokulu, Ormancılık ve Orman Ürünleri Programı, Oltu/Erzurum \\ ${ }^{2}$ Düzce Üniversitesi, Orman Fakültesi, Orman Endüstri Mühendisliği Bölümü, Düzce
}

• Geliş tarihi / Received: 17.05.2017 • Düzeltilerek geliş tarihi / Received in revised form: 26.11.2017 • Kabul tarihi / Accepted: 27.11 .2017

\begin{abstract}
$\ddot{O} z$
Bu çalışmanın amacı, ısıl işlem görmüş (ThermoWood) bazı ağaç türlerinde kullanılan su-bazlı vernik katmanlarının hızlandırılmış UV yaşlandırma direncine karşı yüzey pürüzlülüğünün belirlenmesidir. Bu amaçla Sarıçam (Pinus sylvestris L.), Sapsız Meşe (Quercus petreae L.) ve Doğu kayını (Fagus orientalis L.) odunlarına, ThermoWood metoduna göre $190^{\circ} \mathrm{C}^{\prime}$ de 2 saat ve $212^{\circ} \mathrm{C}^{\prime} \mathrm{de} 1$ ve 2 saat süreler ile ısıl işlem uygulanmıştır. Sonra malzeme yüzeylerine su bazlı tek ve çift bileşenli vernikler uygulanmıştır. Elde edilen malzemeler, UV-A $340 \mathrm{~nm}$ florasan lambalarının bulunduğu UV yaşlandırma cihazında 144, 288 ve 432 saat süre boyunca (ASTM G 154-06) yaşlandırılmaya maruz bırakılmıştır. Bu periyotlar sonralarında yüzey pürüzlülüğü ISO 4287 (1997) değerleri ölçülmüştür. Sonuçlara göre; kullanılan su bazlı tek ve çift bileşenli verniklerin ısıl işlem görmüş ağaç malzeme yüzeylerinde, yaşlandırma sonralarında yüzey pürüzlülüğü değerlerinde azalma tespit edilmiştir.
\end{abstract}

Anahtar kelimeler: Isıl işlem, Su-bazlı vernik, UV yaşlandırma, Yüzey pürüzlülüğü

\begin{abstract}
The purpose of this work is to determine of surface roughness against the effect accelerated UV resistance of water-based varnish layers applied on heat treatment wood (ThermoWood) surfaces. For this purpose, heat treatment was carried out at $190^{\circ} \mathrm{C}$ for 2 hours and at $212^{\circ} \mathrm{C}$ for 1 hour and 2 hours according to the ThermoWood method for Scots pine (Pinus sylvestris L.), Sessile Oak (Quercus petreae L.) and Oriental Beech (Fagus orientalis L.). Then water based single and double component varnishes were applied to the material surfaces. The resulting materials were subjected to aging for 144, 288 and 432 hours (ASTM G 154-06) on a UV aging device with UV-A 340 nm fluorescent lamps. Surface roughness ISO 4287 (1997) values were measured after these periods. According to the results; The surface roughness values of the water-based single and double component varnishes used in the heat treated wood material surfaces were found to decrease after aging.
\end{abstract}

Keywords: Heat Treatment, UV Aging, Water-Based Varnish, Surface roughness

\footnotetext{
*b Nevzat ÇAKICIER; nevzatcakicier@duzce.edu.tr; Tel: (0380) 542 11 37; orcid.org/0000-0001-6566-7541
}

a orcid.org/0000-0002-6787-7822 


\section{Giriş}

Odun, doğal dayanıklılığa sahip bir malzeme olduğu için yüzyıllardır çok yönlü ve yoğun bir kullanım alanına sahip olmakla birlikte diğer tüm biyolojik maddeler gibi çevre faktörlerinin bozundurma etkisine açıktır. $\mathrm{Bu}$ bozundurma olayında ana faktör ultraviyole 1şınlarının (UV) etkisidir. Bununla birlikte, açık hava etkisiyle odunda meydana gelen diğer değişiklikler ise; yüzey ve yüzeye yakın kısımlarda meydana gelen renk değişimi, çatlaklar, yüzey yapısının bozunmas1 ve yağmur suyunun etkisiyle yıkanma olarak özetlenebilir (Temiz 2005).

Ahşap malzemenin korunması için çeşitli metotlar (emprenye, asetillendirme, isıl işlem vb.) geliştirilmiştir. Bu metotlar içinde kimyasal işlem uygulamadan ahşabı korunmasına yönelik olan metot 1 s1l işlem metodudur.

Geçmişten günümüze farklı 1sıl işlem metotları (Finland - ThermoWood, Holland - Plato Wood, Germany - Oil Heat Treatment, France - Bois Perdure, Rectification, vb.) bulunmaktadır.

Yapılan çeşitli çalışmalarda 1sıl işlem sonrasında ahşap malzemede meydana gelen olumlu değişimler belirlenmiştir. Aytin vd. (2015) çalışmalarında, yabani Kiraz (Cerasus avium (L.) Monench) odunun ThermoWood yöntemine göre $190^{\circ} \mathrm{C}^{\prime} \mathrm{de} 1$ saat ve 2 saat ile $212^{\circ} \mathrm{C}^{\prime} \mathrm{de} 1$ saat ve 2 saat varyasyonlarında yapılan 1 sil işlem uygulamaları sonralarında yüzey kalitesinin iyileşmesine yol açtığını bildirmişlerdir.

Altınok vd. (2010) çalışmalarında, 1sıl işlem uygulamasından sonra ağaç malzemelerde, tam kuru yoğunluk ve hava kurusu yoğunluk özelliklerini önemli oranlarda düşürdüğü, şişme ve hacimsel çekme, su geçirgenlik direncinde önemli derecede direnç artış1 görülürken ahşap malzemenin çarpılma veya burulma özellikleri üzerine de olumlu etkisinin bulunduğu belirtilmiştir.

Fakat 1sıl işlem görmüş ahşap malzemenin kullanım yerinde bulunduğu dış ortam şartlarına (don, sıcaklık, güneş 1şını vb.) karşı olan direncini arttırmak için, üst yüzey koruyucu (vernik, boya vb.) kimyasallarının kullanılması gerekmektedir.

$\mathrm{Bu}$ konunun araştırılması ile ilgili olarak Kesik vd. (2015) tarafından yapılan araştırmada, TS EN 3511'e göre $150^{\circ} \mathrm{C}$ 'de 2 saat süre ile bezir yağ 1 içerisinde 1sıl işleme tabi görmüş ve görmemiş sarıçam (Pinus sylvestris L.) odunu örneklerinden elde edilen deney örnekleri yüzeylerine su bazlı vernik ve su bazlı boya uygulanmıştır. Uygulama sonunda yapılan yapışma ve sertlik deneyleri verilerine göre vernik ve boyanın ısıl işlem görmüş ağaç malzeme yüzeyine iyi bir yapışma sağlamış olduğu bildirilmiştir.

Kazan (2009) tarafından yapılan bir araştırmada; 1sıl işlem görmüş $\left(100^{\circ} \mathrm{C}, 125^{\circ} \mathrm{C}\right.$ ve $150^{\circ} \mathrm{C}$ sicaklıklarda ve 2 saat, 4 saat ve 6 saat sürelerde) ve su bazlı vernikler ile verniklenmiş Sarıçam (Pinus sylvestris L.), Doğu kayını (Fagus orientalis L.) ve Kestane (Castanea sativa M.) ağacına ait deney numuneleri üzerinde sertlik, parlaklık ve yüzeye yapışma direnci araştırılmıştır. Araştırma sonuçlarına göre çift kompenantlı verniğin tek kompenantlı verniğe göre daha üstün olduğu belirlenmiştir.

Çeşitli yüzey işlemleri ile kaplanmış ahşap malzemelerin yaşlandırma (doğal veya yapay) sonralarında meydana gelen yüzey pürüzlülüğü değişimlerini belirlemek için Richter vd. (1995) tarafından yapılan bir çalışmada, ön hazırlık işlemlerinin iyi yapılmadığı ağaç malzeme yüzeylerinde boya ve vernik emiliminin daha fazla tüketime sebep olduğu, en iyi yüzey pürüzlülük performansının iyi hazırlık işlemi görmüş malzeme yüzeylerinde elde edildiği ve vernik ile boya tüketim miktarının da yarı yarıya azaldığı bildirilmiştir.

$\mathrm{Bu}$ çalışmanın amacı, ThermoWood metoduna göre $190{ }^{\circ} \mathrm{C}^{\prime}$ de 2 saat ve $212{ }^{\circ} \mathrm{C}^{\prime}$ de 1 ile 2 saat sürelerde 1 sıl işlem görmüş ve su bazlı tek ve çift bileşenli vernikler ile verniklenmiş sarıçam, Doğu kayını ve sapsız meşe odunlarından üretilen malzemelerin hızlandırılmış QUV yaşlandırma cihazında, boya endüstride tercih edilen altı gün ve katları olan; 144, 288 ve 432 saat süreler ile UV 1şınlarına maruz kalmasıyla meydana gelen yüzey pürüzlülüğüne ait değiş̧ikliklerin belirlenmesi amaçlanmıştır.

\section{Materyal ve yöntem}

\subsection{Materyal}

\subsection{1. Örnek Ăgaçların Elde Edilmesi}

Örneklerin hazırlanmasında ülkemizde başta mobilya sektöründe, kaplama ve kontrplak alanlarında en çok kullanılan; sarıçam (Pinus sylvestris L.), Doğu kayını (Fagus orientalis L.) ve sapsız meşe (Quercus petreae L.) türleri tercih edilmiştir. 
Çalışmada kullanılan ağaç malzemeler, Düzce yöresindeki fabrikalardan rastgele seçim yöntemine göre 510x110x20 mm boyutlarında taze halde ölçülendirilerek alınmıştır.

Ağaç malzemenin ardaksız, budaksız, düzgün lifli, büyüme kusurları olmayan, öz ve diri odun kısımları karışık halde alınmıştır. Deney örnekleri eşit olarak radyal ve teğet kesit olmak üzere seçilmiştir (Sönmez ve Söğütlü 2009).

\subsubsection{Deney Örneklerinin Hazırlanması}

$\mathrm{Bu}$ araştırmada, 3 adet ağaç türü (Sarıçam, Doğu kayını ve Meşe) x 3 adet 1 sil işlem $\left(190{ }^{\circ} \mathrm{C}\right.$ 'de 2 saat, $212^{\circ} \mathrm{C}^{\prime}$ de 1 ve 2 saat) x 2 adet vernik türü (subazlı tek ve çift bileşenli vernikler) $\mathrm{x} 4$ adet yaşlandırma uygulaması $(0,144$ saat, 288 saat ve 432 saat) olmak üzere toplamda 72 adet deney numunesi hazırlanmıştır.

Keresteler ortalama $20 \pm 2^{\circ} \mathrm{C}$ sicaklik ve $\% 65 \pm 5$ bağıl nemli iklimlendirme odasında değişmez ağırlığa ulaşıncaya kadar bekletilerek rutubetlerinin \%12'ye gelmesi sağlanmıştır (TS 642 1997).

\subsection{Yöntem}

\subsubsection{Isıl İşlem Uygulamast}

$\mathrm{Bu}$ çalışmada kullanılan ağaç malzemeler, BoluGerede de bulunan Nova Orman Ürünleri San. Tic. A.Ş.'nde tercih edilmekte olan; $190^{\circ} \mathrm{C}$ 'de 2 saat, $212^{\circ} \mathrm{C}^{\prime}$ de 1 saat ve 2 saat sürelerinde ThermoWood yöntemine göre 1sıl işleme tabi tutulmuştur (Anonymous, 2003).

Is1l işlem görmüş keresteler TS 642 (1997) standardına göre ortalama $20 \pm 2^{\circ} \mathrm{C}$ sicaklık ve $\% 65 \pm 5$ bağıl nemli iklimlendirme odasında değişmez ağırllğa gelinceye kadar bekletildikten sonra deneysel çalışmalara geçilmiştir.

Daha sonra test örnekleri endüstriyel uygulamalara uygun olarak kalibre zimpara makinesinde önce 100,120 ve daha sonra 180 nolu zimpara ile zımparalanmıştır (Ayata 2014).

\subsubsection{Su-Bazlı Verniklerin Uygulanmast}

Ağaç malzeme dış ortam şartlarında (soğuk, sıcak vb.) çatlama, kırılma gibi önemli olumsuzluklara maruz kalmaktadır. Bu olumsuz sonuçları azaltmak için esnek film katmanı oluşturan ve çevreye duyarlı su bazlı vernikler tercih edilmiştir.

\subsubsection{Astar Vernik Uygulaması}

Is1l işlem görmüş ahşap keresteleri 180 nolu zımpara ile zımparalanmış 500x100x14 mm boyutlarında temiz ölçüsüne getirilmiştir.

Isıl işlem görmüş sarıçam, kayın ve meşe keresteleri; DUAL Boya Firması'ndan temin edilen ve firma önerilerine göre uygulamaya hazır hale getirilen AQUACOOL FX 6150 kodlu biyosit ve lignin koruyucu içeren renksiz astar ile 10 sn'lik daldırma periyoduna göre iki kat olarak uygulanmıştır.

Katlar arasında $20{ }^{\circ} \mathrm{C}$ ortam sicaklığında 3 saat beklendikten sonra kuruyan vernik filmi 400 nolu su zımparası ile zımparalanmış ve tozlar temizlendikten sonra ikinci kat uygulaması yapılmıştır.

Tam kuruması sağlanan astar katı, 400 numara zımpara ile zımparalanarak tozlar temizlendikten sonra su bazlı tek ve çift bileşenli son kat vernik uygulamalarına geçilmiştir (Ayata 2014).

\subsubsection{Su-Bazlı Tek ve Çift Bileşenli Verniklerin Uygulamast}

Son kat su bazlı tek bileşenli vernik uygulamasında Dual Boya Firmasının AQUACOOL FX 7680/00 Dış Mekân renksiz son kat verniği kullanılmıştır.

Son kat su bazlı çift bileşenli vernik uygulamasında Dual Boya Firmasının AQUACOOL 0820/00 Dış Mekân renksiz son kat verniği (vernik + AQUACOOL AX 0115 sertleştirici $(\% 25)+$ su (\%10)) kullanılmıştır.

Su-bazlı tek ve çift bileşenli verniklerin uygulamasinda endüstriyel uygulamalara uygun olarak Tablo 1'de verilen miktarlarda tatbik edilmiştir. Uygulamada tabanca uç açıklığı $2.0 \mathrm{~mm}$ olan üstten hazneli püskürtme tabancas1 kullanılmıştır.

Püskürtme tabancası ile endüstriyel yüzey uygulaması yönelik olarak numune yüzeyine dik ve uzaklığ $20-25 \mathrm{~cm}$ olacak şekilde paralel hareket ettirilerek, her katta önce liflere dik sonra liflere paralel olmak üzere çapraz kat yapılmıştır. Uygulamadaki hava basincı 2 bar olarak seçilmiştir.

Su bazlı tek bileşenli vernik uygulamasında birinci kat uygulandıktan sonra $20^{\circ} \mathrm{C}$ ortam sicaklığında 3 saat beklenmiş ve kurutulmuş katman 400 nolu su 
zımparası ile zımparalandıktan sonra ikinci kat uygulanmıştır.

Uygulama sirasında Tablo 4'de verilen verniklere ait katı madde miktarlarının oranlarına göre film katman kalınlıklarının birbirine eşit olmasına özen gösterilmiştir (Ayata 2014).
Su bazlı çift bileşenli vernik uygulamasında birinci kat uygulandıktan sonra $20^{\circ} \mathrm{C}$ ortam sicaklığında 3 saat beklenmiş ve kurutulmuş katman 400 nolu su zımparası ile hafifçe zımparalandıktan sonra ikinci kat uygulanmıştır.

Tablo 1. Vernik uygulamaları (Ayata 2014)

\begin{tabular}{|c|c|c|}
\hline \multicolumn{3}{|l|}{ Tek bileşenli vernik uygulaması } \\
\hline \multirow[b]{2}{*}{ FX 6150 UV Koruyucu Astar Daldırma yöntemi } & 1. kat $130 \mathrm{~g} / \mathrm{m}^{2}$ & $25 \mathrm{~g} / \mathrm{m}^{2}$ \\
\hline & 2. kat $70 \mathrm{~g} / \mathrm{m}^{2}$ & $13 \mathrm{~g} / \mathrm{m}^{2}$ \\
\hline \multirow{2}{*}{ FX 7680 Son Kat Vernik Pistole yöntemi } & 1. kat $140 \mathrm{~g} / \mathrm{m}^{2}$ & $61 \mathrm{~g} / \mathrm{m}^{2}$ \\
\hline & 2. kat $140 \mathrm{~g} / \mathrm{m}^{2}$ & $61 \mathrm{~g} / \mathrm{m}^{2}$ \\
\hline Toplam Katı Madde & & $160 \mathrm{~g} / \mathrm{m}^{2}$ \\
\hline \multicolumn{3}{|l|}{ Çift bileşenli vernik uygulaması } \\
\hline \multirow{2}{*}{ FX 6150 UV Koruyucu Astar Daldırma yöntemi } & 1. kat $130 \mathrm{~g} / \mathrm{m}^{2}$ & $25 \mathrm{~g} / \mathrm{m}^{2}$ \\
\hline & 2. kat $70 \mathrm{~g} / \mathrm{m}^{2}$ & $13 \mathrm{~g} / \mathrm{m}^{2}$ \\
\hline \multirow{3}{*}{ FX 0820 2K Son Kat Vernik Pistole yöntemi } & 1. kat $105 \mathrm{~g} / \mathrm{m}^{2}$ & $40 \mathrm{~g} / \mathrm{m}^{2}$ \\
\hline & 2. kat $105 \mathrm{~g} / \mathrm{m}^{2}$ & $40 \mathrm{~g} / \mathrm{m}^{2}$ \\
\hline & 3. kat $105 \mathrm{~g} / \mathrm{m}^{2}$ & $40 \mathrm{~g} / \mathrm{m}^{2}$ \\
\hline Toplam Katı Madde & & $158 \mathrm{~g} / \mathrm{m}^{2}$ \\
\hline
\end{tabular}

Tablo 2. Uygulanan vernikler hakkında bilgiler (Ayata 2014)

\begin{tabular}{|c|c|c|c|c|c|c|c|}
\hline Vernik Türleri & Bileşeni & $\begin{array}{l}\text { Yoğun } \\
\text {-luk }\end{array}$ & $\mathrm{pH}$ & $\begin{array}{c}\text { Kat1 } \\
\text { Madde } \\
(\%) \\
\end{array}$ & Uygulama Metodu & Viskozite & $\begin{array}{c}\text { Uygulanan } \\
\text { Miktar } \\
\left(\mathrm{g} / \mathrm{m}^{2}\right) \\
\end{array}$ \\
\hline $\begin{array}{c}\text { FX } 6150 \\
\text { UV koruyucu } \\
\text { astar }\end{array}$ & $\begin{array}{l}\text { Akrilik reçine, } \\
\text { biyosit ve UV } \\
\text { koruyucu }\end{array}$ & 1.02 & 9.2 & $19 \pm 2$ & $\begin{array}{l}\text { Tercihen daldırma } \\
\text { yöntemi, rulo, firça, } \\
\text { bez, sünger }\end{array}$ & $\begin{array}{c}\text { DIN } 4 \text { kabinda } \\
20^{\circ} \mathrm{C} \text { 'de } 11 \text { saniye }\end{array}$ & $\begin{array}{c}\text { Tek } \\
\text { katta } \\
100\end{array}$ \\
\hline $\begin{array}{c}\text { FX } 7680 \\
\text { dış mekân parlak } \\
\text { vernik }\end{array}$ & $\begin{array}{l}\text { Akrilik ve alifatik } \\
\text { PU reçine }\end{array}$ & 1.05 & 9.3 & $42 \pm 2$ & Pistole, firça & $\begin{array}{l}\text { DIN } 6 \text { kabinda } \\
20^{\circ} \mathrm{C} \text { 'de } 45-55 \\
\text { saniye }\end{array}$ & $100-140$ \\
\hline $\begin{array}{c}\text { FX } 0820 \text { diş } \\
\text { mekân parlak } \\
\text { vernik } 2 \mathrm{~K}\end{array}$ & $\begin{array}{l}\text { Alifatik PU } \\
\text { dispersiyon }\end{array}$ & 1.03 & 8.5 & $32 \pm 2$ & $\begin{array}{l}\text { Pistole, basınçlı } \\
\text { pompa }\end{array}$ & $\begin{array}{c}\text { DIN } 4 \text { kabında } \\
20^{\circ} \mathrm{C} \text { 'de } 35-45 \\
\text { saniye (AX } 015 \\
\text { sertleştirici } \\
\text { katılmış hali ile) }\end{array}$ & $60-100$ \\
\hline $\begin{array}{l}\text { AX } 0115 \\
\text { sertleştirici }\end{array}$ & $\begin{array}{l}\text { Suda çözünen } \\
\text { alifatik poli } \\
\text { izosiyanat }\end{array}$ & - & - & $66-72$ & - & - & - \\
\hline
\end{tabular}

İkinci kat uygulamasından sonra $20{ }^{\circ} \mathrm{C}$ ortam sıcaklığında 3 saat beklenmiş ve kurutulmuş katman 400 nolu su zımparası ile hafifçe zımparalandıktan sonra üçüncü kat uygulanmıştır.

Uygulama sirasında Tablo 4'de verilen verniklere ait katı madde miktarlarının oranlarına göre film katman kalınlıklarının birbirine eşit olmasına özen gösterilmiştir.

Üretici firma tarafindan takım halinde temin edilen su-bazlı tek ve çift bileşenli verniklerin bazı teknik özellikleri Tablo 1'de verilmiştir (Ayata 2014).

\subsubsection{Hızlandırılmış UV Yaşlandırma Uygulamast Öncesi Deney Örneklerinin Hazırlanması}

Isıl işlem görmüş ve su bazlı tek ve çift bileşenli vernikler ile verniklenmiş 500x100x14 mm boyutlarındaki örnekler, yaşlandırma cihazına ait panel tutuculara uygun olarak, 120x80x14 mm boyutlarında kesildikten sonra elde edilen malzemelerin vernik bulunmayan açı kenarları, yaşlandırma uygulamaları sırasında herhangi bir olumsuz etkilere maruz kalmaması için aynı tür 
vernik ile verniklenerek yaşlandırma işlemlerine hazır hale getirilmiştir (Ayata 2014).

\subsubsection{Hızlandırılmış UV Yaşlandırma Uygulamast}

Sarıçam, kayın ve meşe odunlarına ait deney örneklerine, su bazlı tek ve çift bileşenli vernikler uygulandiktan sonra iklimlendirme laboratuvarında $\% 12$ rutubet için $20 \pm 2^{\circ} \mathrm{C}$ sicaklık ve $\% 65 \pm 3$ bağıl nem şartlarında üç hafta süreyle kurumaya bırakılmıştır (Ayata 2014).

Daha sonra verniklenmiş deney örnekleri ASTM G 154-06 (2006) standardına (15 dakika su sprey, 8 saat UV) ait yaşlandırma ortam koşullarının modifiye edilmesiyle hazırlanmış ( 0.67 1şık şiddeti, 18 dakika su sprey, 2 saat UV ve $50{ }^{\circ} \mathrm{C}$ ortam sıcaklığı) ve UV-A 340 florasan lambalarının olduğu yaşlandırma cihazında (QUV accelerated weathering tester) 144,288 ve 432 saat süreleri boyunca UV yaşlandırma etkilerine bırakılmışır (Ayata 2014).

\subsubsection{Katt Madde Tayini}

Katı madde tayininin amacı; eşit kalınlıkta katman hazırlayabilmek için vernik veya boyanın katman yapma özelliğini tespit etmektir.

Bunun için; ASTM D 1644-01 (2006) esaslarına uyularak; vernikler, darası önceden alınan Ø $75 \pm 5$ mm'lik konkav saat camına $2 \pm 0.2$ g olacak şekilde damlalık ile konulmuş, daha sonra etüvde $60^{\circ} \mathrm{C}$ 'de ağırlıkça sabit hale gelene kadar bekletilmiştir. $\mathrm{Bu}$ süre sonunda çözücüler tamamen buharlaștırılarak yeniden tartımları yapılmıştır. Katı madde miktarları aşağıdaki formül yardımıyla hesaplanmıştır.

$$
\begin{aligned}
& \mathrm{Km}=[(\mathrm{Vu}-\mathrm{Çb}) / \mathrm{Vu}] \times 100 \\
& \mathrm{Vu}=\mathrm{G}-\mathrm{D}, \\
& \mathrm{Çb}=\mathrm{G}-\mathrm{E}, \\
& \text { Burada; } \\
& \mathrm{Vu}=\text { Uygulanan vernik }(\mathrm{g}), \\
& \mathrm{Çb}=\text { Buharlaşan çözücü (g), } \\
& \mathrm{Km}=\text { Katı madde }(\%) \\
& \mathrm{G}=\text { Yaş ağırlı }(\mathrm{g}), \\
& \mathrm{D}=\text { Dara (g), } \\
& \mathrm{E}=\text { Kuru ağırlı }(\mathrm{g}) .
\end{aligned}
$$

\subsubsection{Emprenye Retensiyon Oranlarinin Belirlenmesi}

Firma önerilerine göre uygulamaya hazır hale getirilen AQUACOOL FX 6150 kodlu renksiz astar verniğinin uygulanmasında kısa süreli emprenye daldırma metodu kullanılmış olup, deney numuneleri 10 saniye süre ile emprenye maddesi içerisinde 2 defa bırakılmıştır.

Emprenye edilen örneklerin absorbe ettikleri çözelti miktarları ve net kuru madde miktarları TS 5723 (1988) standardinda belirtilen esaslar çerçevesinde aşağıdaki formüllere göre hesaplanmıştır (Bozkurt vd. 1993).

Retensiyon $=\frac{G \times C}{V} \times 10 \mathrm{~kg} / \mathrm{m}^{3}$

Eşitlikte;

$\mathrm{G}=$ Örnek tarafından absorbe edilen çözelti miktarı $\left(\mathrm{m}_{1}-\mathrm{m}_{0}\right)(\mathrm{g})$

$\mathrm{m}_{0}=$ Emprenye öncesi ağılık $(\mathrm{g})$

$\mathrm{m}_{1}=$ Emprenye sonrası yaş ağırlık $(\mathrm{g})$

$\mathrm{C}=$ Çözelti konsantrasyonu

$\mathrm{V}=$ Odun örneğinin hacmi $\left(\mathrm{cm}^{3}\right)^{\prime}$ dir.

Retensiyon $=\frac{\text { Moes }- \text { Moeö }}{\text { Moeö }} \times 100$

Eşitlikte;

Moes = Emprenye sonras1 numunenin tam kuru ağırlığ 1 (g)

Moeö = Emprenye öncesi numunenin tam kuru ağırlığ 1 (g)

$\mathrm{C}=$ Çözelti konsantrasyonu (\%).

\subsubsection{Kuru Film Kalınlıklart}

Çalışmada kullanılan verniklerin kuru film katman kalınlıkları Şekil 1'de gösterilen PosiTector 200 cihazında ASTM D 6132 (2008) standardında belirtilen esaslara uyularak belirlenmiştir.

Çeşitli mikron kalınlıklarına sahip film tabakaları ile kalibresi doğrulanan cihazın probu, vernikli ahşap malzeme üzerine damlatılan jel (DeFelsko marka - Ultrasonic couplant)'in üstüne gelecek şekilde bastırılmaktadır.

Cihaz ultrasonik olarak çoklu sinyal gönderdikten hemen sonra tarama yapması ile otomatik olarak mikron kalınlığına ait değer ekranda okunmaktadır (Ayata 2014). 


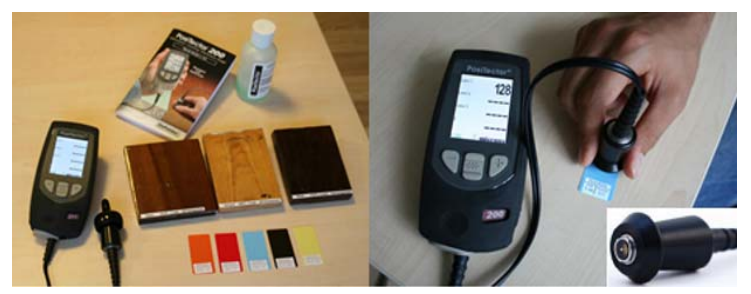

Şekil 1. PosiTector 200 cihazı (Ayata 2014).

\subsubsection{Yüzey Pürüzlü̈lüğ̈̈ Ölçümü}

Yüzey pürüzlülüğü ölçümlerinde, ardışık profil değişikliklerini ölçebilen Mitutoyo Surftest SJ-301 dokunmalı (iğneli) yüzey pürüzlülük ölçüm aleti kullanılmıştır (Şekil 2).

Cihaz, pürüzlülük ölçümünde, $5 \mu \mathrm{m}$ çaplı elmas ucunu örnek yüzeyinde aşağıya-yukarıya hareket ettirerek yüzeydeki girinti ve çıkıntıların profilini çıkararak, ölçüm yapmaktadır (Korkut 1999; Ayata 2014).

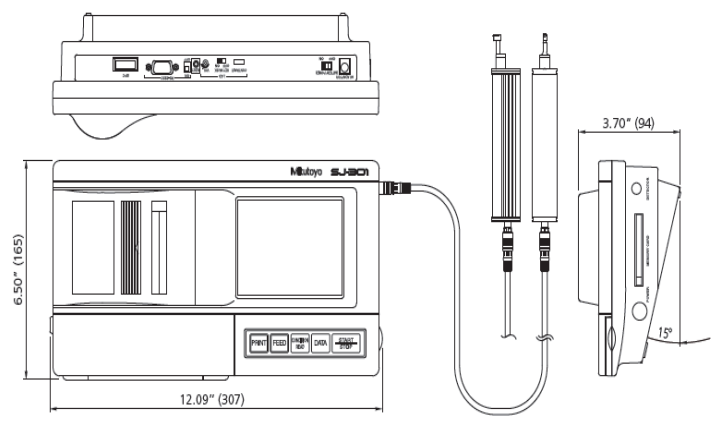

Şekil 2. Mitutoyo surftest SJ-301 cihazının dış görünüşü (Portable Surface roughness tester surftest Sj-301 kullanım k1lavuzu 1998).

Her yaşlandırma periyodu sonunda yüzey pürüzlülük ölçümleri yapılmıştır. Alet ölçme hızı $10 \mathrm{~mm} /$ dak ve iğne çap $4 \mu \mathrm{m}$ olarak seçilmiştir. Ölçme liflere dik yönde yapılmış, değerlendirme uzunluğu (tarama uzunluğu) $\mathrm{Lt}=15 \mathrm{~mm}$, örnekleme uzunluğu (sınır dalga boyu $\lambda=2,5 \mathrm{~mm}$ seçilerek pürüzlülük değeri $\pm 0,5 \mathrm{~mm}$ duyarlılıkta belirlenmiştir (Korkut 1999; Ayata 2014).

Ölçmelerde tarama iğnesinin örnek yüzeylerinde kusurlara (çizik, kesik vb.) yol açmaması için alet tarama kolu yükü 10 gramdan düşük tutulmuş; tarama iğnesi ucu hücre boşluklarına takıldığında ölçme tekrarlanmıştır. Ölçme ortamı gürültü kaynaklarından uzak tutulmuş, aletin yerleştirildiği masa titreşimleri önleyici yalıtkan bir malzeme ile kaplanmıştır. Ayrıca ortam sıcaklığının $18-22^{\circ} \mathrm{C}$ arasında olmasına özen gösterilmiştir (Korkut 1999).
Örneğin ve cihazın yer düzlemine paralelliği kontrol ve ayar edildikten sonra $R_{\mathrm{a}}, R_{\mathrm{z}}$ ve $R_{\max }=R_{\mathrm{y}}$ değerleri ISO 4287 (1997) standardına göre belirlenmiştir. Her numunede toplam on ölçüm yapılmıştır. Ölçme hassasiyetinin sürekliliği için her yaşlanma periyotlarında kalibrasyon tekrar yapılmıştır (Ayata 2014).

\subsubsection{Verilerin Değerlendirilmesi}

İstatistiksel analiz sonuçları, 10'ar adet ölçüm sayıs1 alınarak, kontrol örnekleri (yaşlandırma öncesi) ile yaşlandırma uygulaması sonrasında tahribatların oluştuğu örneklerin karşılaştırılması sonucu elde edilmiştir.

Bu çalışmada, 3 adet ağaç türü (Sarıçam, Doğu kayını ve Meşe) x 3 adet 1 sıl işlem $\left(190{ }^{\circ} \mathrm{C}\right.$ 'de 2 saat, $212^{\circ} \mathrm{C}^{\prime}$ de 1 ve 2 saat) $\mathrm{x} 2$ adet vernik türü (subazlı tek ve çift bileşenli vernikler) $\mathrm{x} 4$ adet yaşlandırma uygulaması $(0,144$ saat, 288 saat ve 432 saat) x 3 adet yüzey pürüzlülük faktörü $\left(R \mathrm{a}, R_{\mathrm{z}}\right.$ ve $\left.R_{\max }\right)$ x 10 adet ölçüm sayısı olmak üzere toplamda 2160 adet ölçüm alınmıştır.

İstatistiksel değerlendirmeler için MSTATC istatistik paket programı kullanılmıştır.

Çoklu varyans analizi "ANOVA" testleri sonucunda, ağaç türü, 1sıl işlem, vernik çeşidi ve yaşlandırma periyodu faktörlerinin, ağaç malzeme üzerindeki yüzey pürüzlülüğü testlerine göre faktör etkileri ve karş1lkklı etkileşimleri belirlenmiştir. Duncan testi ve LSD (en küçük önemli fark) kritik değerleri yardımıyla karşılaştırmalar yapılarak homojenlik grupları oluşturularak farklılığın hangi faktörlerden kaynaklandığı sorgulanmıştır.

\section{Bulgular ve Tartışma}

\subsection{Kullanılan Verniklerin Ö̈elliklerine Ait Bulgular}

\subsubsection{Katı Madde Oranlarının Belirlenmesi}

Çalışmada kullanılan verniklerin katı madde miktarlarına ilişkin sonuçları Tablo 3'de verilmiştir. En yüksek katı madde oranı; su bazlı tek bileşenli vernikte, en düşük ise emprenye renksiz dolgu verniği FX 6150'de elde edilmiştir.

Tablo 3. Kullanılan verniklerin katı madde miktarları (\%).

\begin{tabular}{|l|l|}
\hline Vernik Çeşidi & $\begin{array}{c}\text { Katı Madde } \\
\text { Oranı (\%) }\end{array}$ \\
\hline
\end{tabular}




\begin{tabular}{|l|c|}
\hline Emprenye Dolgu Renksiz FX 6150 UV & 19.45 \\
\hline Su Bazlı Tek Bileşenli Vernik (FX 7680) & 43.26 \\
\hline $\begin{array}{l}\text { Su Bazlı Çift Bileşenli Vernik (FX 0820 } \\
\text { 2K + AX 0115 sertleştirici) }\end{array}$ & 37.78 \\
\hline
\end{tabular}

\subsubsection{Emprenye Retensiyon Oranlarının Belirlenmesine ve Kuru Film Kalınlıklarına İlişkin Bulgular}

ThermoWood metoduna göre 1sıl işlem görmüş sarıçam, kayın ve meşe odunlarının retensiyon oranları Tablo 4'de verilmiştir. Isıl işlem görmüş ağaç malzemelere uygulanan 2 defa 10 saniyelik emprenye işleminin sonunda; en yüksek net kuru madde miktar1 ve retensiyon oran $1 ; 212{ }^{\circ} \mathrm{C}$ 'de 2 saat 1sıl işlem görmüş sarıçam örneğinde, en düşük ise $190{ }^{\circ} \mathrm{C}$ 'de 2 saat 1 sil işlem görmüş kayın örneğinde elde edilmiştir. Isıl işlem süresi ve sicaklığın artmasına paralel olarak net kuru madde miktarı ve \% retensiyon miktarının arttığı tespit edilmiştir.

Su bazlı tek ve çift bileşenli verniklerin kuru film kalınlıklarına ilişkin ölçüm sonuçları Tablo 5'de verilmiştir. Tablo 5'e göre katman kalınlığ en yüksek $212{ }^{\circ} \mathrm{C}$ 'de 2 saat 1 sıl işlem görmüş ve çift bileşenli vernik ile verniklenmiş meşede, en düşük $212{ }^{\circ} \mathrm{C}$ 'de 1 saat süre ile 1 ssil işlem görmüş ve tek bileşenli vernik ile verniklenmiş kayında elde edilmiştir.

Tablo 4. ThermoWood metoduna göre 1 sıl işlem görmüş ağaç türlerine ait net kuru madde miktarları ve \% tutunma oranları.

\begin{tabular}{|c|c|c|c|}
\hline Ağaç türü & Isıl işlem & Net kuru madde miktarları $\left(\mathrm{kg} / \mathrm{m}^{3}\right)$ & $\%$ Tutunma \\
\hline \multirow{3}{*}{ Sarıçam } & $190^{\circ} \mathrm{C}^{\prime} \mathrm{de} 2$ saat & 9.8089 & 10.34 \\
\hline & $212^{\circ} \mathrm{C}^{\prime} \mathrm{de} 1$ saat & 12.2580 & 11.86 \\
\hline & $212^{\circ} \mathrm{C}^{\prime}$ de 2 saat & 12.9515 & 14.05 \\
\hline \multirow{3}{*}{ Kayın } & $190^{\circ} \mathrm{C}^{\prime}$ de 2 saat & 6.2698 & 4.09 \\
\hline & $212^{\circ} \mathrm{C}^{\prime}$ de 1 saat & 6.8494 & 4.94 \\
\hline & $212^{\circ} \mathrm{C}^{\prime}$ de 2 saat & 7.5817 & 5.41 \\
\hline \multirow{3}{*}{ Meşe } & $190^{\circ} \mathrm{C}$ 'de 2 saat & 6.5139 & 4.57 \\
\hline & $212^{\circ} \mathrm{C}^{\prime}$ de 1 saat & 6.6969 & 5.20 \\
\hline & $212^{\circ} \mathrm{C}^{\prime}$ de 2 saat & 6.8342 & 5.25 \\
\hline
\end{tabular}

Tablo 5. Kuru film kalınlıkları.

\begin{tabular}{|c|c|c|c|}
\hline Ağaç türü & Isıl işlem & Vernik çeşidi & Katman kalınlığ $1(\mu \mathrm{m})$ \\
\hline \multirow{6}{*}{ Sarıçam } & \multirow{2}{*}{$190^{\circ} \mathrm{C}$ 'de 2 saat } & Tek Bileșenli & 139.80 \\
\hline & & Çift Bileşenli & 155.00 \\
\hline & \multirow[b]{2}{*}{$212^{\circ} \mathrm{C}^{\prime}$ de 1 saat } & Tek Bileșenli & 140.80 \\
\hline & & Çift Bileșenli & 155.40 \\
\hline & \multirow{2}{*}{$212^{\circ} \mathrm{C}^{\prime}$ de 2 saat } & Tek Bileșenli & 144.00 \\
\hline & & Çift Bileșenli & 154.60 \\
\hline \multirow{6}{*}{ Kayın } & \multirow{2}{*}{$190^{\circ} \mathrm{C}$ 'de 2 saat } & Tek Bileşenli & 137.00 \\
\hline & & Çift Bileşenli & 152.00 \\
\hline & \multirow{2}{*}{$212^{\circ} \mathrm{C}^{\prime}$ de 1 saat } & Tek Bileșenli & 136.40 \\
\hline & & Çift Bileșenli & 151.80 \\
\hline & \multirow{2}{*}{$212^{\circ} \mathrm{C}^{\prime}$ de 2 saat } & Tek Bileșenli & 139.00 \\
\hline & & Çift Bileșenli & 152.40 \\
\hline \multirow{6}{*}{ Meşe } & \multirow{2}{*}{$190^{\circ} \mathrm{C}$ 'de 2 saat } & Tek Bileşenli & 142.00 \\
\hline & & Çift Bileșenli & 153.80 \\
\hline & \multirow{2}{*}{$212^{\circ} \mathrm{C}$ 'de 1 saat } & Tek Bileşenli & 147.00 \\
\hline & & Çift Bileșenli & 156.60 \\
\hline & \multirow{2}{*}{$212^{\circ} \mathrm{C}^{\prime}$ de 2 saat } & Tek Bileşenli & 148.60 \\
\hline & & Çift Bileşenli & 158.20 \\
\hline
\end{tabular}

\subsubsection{Yüzey Pürüzlülü̆ğ̈̈ Değerlerine İlişkin Bulgular}

Farklı sıcaklık ve sürelerde 1sıl işlem görmüş, farklı ağaç malzemelerin, su bazlı tek ve çift bileşenli vernikler ile verniklendikten sonra yaşlandırma uygulamasına maruz birakılan deney örneklerinde elde edilen ortalama yüzey pürüzlülüğü $R \mathrm{a}, R_{\mathrm{z}}$ ve $R_{\max }$ değerleri ait Çoklu Varyans analizi (ANOVA) belirlenmiş ve bu sonuçları Tablo 6'da verilmiştir. 
Tablo 6 incelendiğinde $R \mathrm{a}, R_{\mathrm{z}}$ ve $R_{\max }$ değerleri için yapılan varyans analiz sonucuna göre ağaç türü, ısıl işlem, vernik çeşidi ve yaşlandırma periyodu faktörleri ve bu faktörlerin karşılıklı etkileşimleri anlamlı çıktığı belirlenmiştir $(\alpha=0.05)$.

Tablo 7'ye göre ağaç türü düzeyinde yüzey pürüzlülüğü $R_{\mathrm{a}}$ değeri en yüksek sarıçamda, en düşük meşede, $R_{\mathrm{z}}$ ve $R_{\max }$ değerleri en yüksek meşede, en düşük sarıçamda belirlenmiştir.

Is1l işlem düzeyinde, yüzey pürüzlülüğü $R_{\mathrm{a}}, R_{\mathrm{z}}$ ve $R_{\max }$ değerleri en yüksek $212^{\circ} \mathrm{C}^{\prime}$ de 1 saat isıl işlem görmüş örneklerde, en düşük $190^{\circ} \mathrm{C}$ 'de 2 saat 1 sıl işlem görmüş örneklerde elde edilmiştir.

Vernik çeşidi faktörü düzeyinde yüzey pürüzlülüğü $R_{\mathrm{a}}$ değeri en yüksek çift bileşenli vernikte, $R_{\mathrm{z}}$ ve $R_{\max }$ değerleri en yüksek tek bileşenli vernikte, en düşük $R_{\mathrm{a}}$ değeri tek bileşenli vernikte ve en düşük $R_{\mathrm{z}}$ ve $R_{\max }$ değerleri çift bileşenli vernikte elde edilmiştir.

Yaşlandırma periyodu düzeyinde yüzey pürüzlülüğü $R_{\mathrm{a}}$ değeri en yüksek kontrol örneklerinde, en düşük 432 saatlik UV yaşlandırmaya maruz kalmış örneklerinde, $R_{\mathrm{z}}$ değeri en yüksek 144 ve 288 saatlik UV yaşlandırmaya maruz kalmış örneklerinde, en düşük kontrol örneklerinde tespit edilmiştir.

$R_{\max }$ değeri en yüksek 144 saatlik UV yaşlandırmaya maruz kalmış örneklerinde, en düşük kontrol örneklerinde tespit edilmiştir.

Tekli, ikili ve üçlü karşılaştırma sonuçlarını topluca görmek amacıyla, ağaç türü - 1sıl işlem vernik çeşidi - yaşlandırma periyodu etkileşimi düzeyinde yapılan Duncan testi karşılaştırma sonuçları Tablo 8'de verilmiştir.

Tablo 8'e göre ağaç türü - 1sıl işlem - vernik çeşidi - yaşlandırma periyodu etkileşimi düzeyinde, yüzey pürüzlülüğü $R_{a}$ değeri en yüksek, $212^{\circ} \mathrm{C}$ 'de 1 saat süre ile 1 sıl işlem görmüş ve çift bileşenli vernik ile verniklenmiş sarıçamın kontrol örneklerinde, en düşük $212^{\circ} \mathrm{C}^{\prime}$ de 1 saat süre ile 1 sıl işlem görmüş ve tek bileşenli vernik ile verniklenmiş meşenin 432 saatlik UV yaşlandırma periyoduna ait örneklerde elde edilmiştir.

$\mathrm{R}_{\mathrm{z}}$ değeri için ağaç türü - 1sıl işlem - vernik çeşidi yaşlandırma periyodu etkileşimi düzeyinde, yüzey pürüzlülüğü en yüksek, $212^{\circ} \mathrm{C}$ 'de 1 saat süre ile $1 s 11$ işlem görmüş ve tek bileşenli vernik ile verniklenmiş meşenin 144 saatlik UV yaşlandırma yapılan örneklerinde, en düşük $190^{\circ} \mathrm{C}$ 'de 2 saat ve $212^{\circ} \mathrm{C}$ 'de 1 saat süre ile 1 sıl işlem görmüş ve çift bileşenli vernik ile verniklenmiş sarıçamın kontrol ve $212^{\circ} \mathrm{C}^{\prime}$ de 1 saat süre ile 1 șl işlem görmüş ve çift bileşenli vernik ile verniklenmiş kayın kontrol örneklerinde tespit edilmiştir.

$R_{\max }$ değeri için ağaç türü - 1sıl işlem - vernik çeşidi - yaşlandırma periyodu etkileşimi düzeyinde, yüzey pürüzlülüğü en yüksek, $212^{\circ} \mathrm{C}^{\prime}$ de 1 saat süre ile 1sıl işlem görmüş ve tek bileşenli vernik ile verniklenmiş meşenin 144 saatlik UV yaşlandırma yapılan örneklerinde, en düşük $212^{\circ} \mathrm{C}^{\prime}$ de 1 saat süre ile 1sıl işlem görmüş ve çift bileşenli vernik ile verniklenmiş kayının kontrol örneklerinde ve $190^{\circ} \mathrm{C}$ 'de 2 saat süre ile 1 s1l işlem görmüş ve çift bileşenli vernik ile verniklenmiş sarıçamın kontrol örneklerinde belirlenmiştir.

Aytin (2013) çalışmasında, yabani kiraz odununda 1s1 işlem sonrasında yüzey düzgünlügünün $\operatorname{arttığını,~} R_{\mathrm{a}}$ değerinin sıcaklık ve süre artışına bağlı olarak daha küçük değerler aldığını bildirmiştir. Ayrıca higroskopik karakteri yüksek bileşenlerin 1sıl işlemle birlikte odundan uzaklaşması ile artan hidrofobik özellik ve düşük denge rutubeti içeriği nedeniyle odun-su ilişkisinin kısıtlanması yüzeyde meydana gelebilecek deformasyonu azaltabileceği gibi yüksek sicaklıklarda ligninin plastikleşmesi ve kapalı bir yüzey teşkili ile yüzeydeki deformasyonları azaltabilecek bir etken olduğunu ifade etmiştir.

Özcan vd. (2012) sarıçam, Doğu kayını, beyaz meşe ve Uludağ göknarında isıl işlem ve yüzey kabalığının yapıştırma direncine etkisini belirlerken, en yüksek $R_{\mathrm{a}}$ 'nın beyaz meşede görüldüğünü, 1sıl işlemin tüm ağaç türlerinde yüzey kalitesini iyileştirdiğini bildirmiştir.

Unsal ve Ayrilmis (2005) çalışmalarında, termal olarak modifiye edilmiş okaliptüs odununun liflere dik yöndeki yüzey pürüzlülüğü (ortalama pürüzlük) değerinin, 1 sıl işlem sıcaklı̆̆ 1 ve işlem süresi uzadıkça azaldığı bildirilmiştir.

Korkut ve Budakçı (2010) çalışmalarında 1sıl işlem ile ağaç malzemede yüzey pürüzlülüğünün azaldığını bildirirken, ısıl işlem süresince özellikle $160^{\circ} \mathrm{C}$ üzerindeki sıcaklıklarda ahşap malzemede 1sının etkisiyle ligninin termoplastikleşme özelliği kazanacağı ve yoğunluğunun artabileceği belirtilmiştir.

Bakar vd. (2013) yüksek sıcaklık uygulanmış ağaç malzemelerde yüzey kalitesinin iyileştĭgini belirterek bunun hücre çeperindeki biyokimyasal 
değişmelerden kaynaklanmış olabileceğini

bildirmişlerdir.

Tablo 6. Ağaç türü, ısıl işlem, vernik çeşidi ve yaşlandırma periyodunun yüzey pürüzlülüğü $R \mathrm{a}, R_{\mathrm{z}}$ ve $R_{\max }$ değerlerine ilişkin varyans analizi sonuçları.

\begin{tabular}{|c|c|c|c|c|c|c|}
\hline Test & Varyasyon Kaynağ 1 & Serbestlik Derecesi & Kareler Toplam1 & Ortalama Kare & F Değeri & $P, \alpha=0.05$ \\
\hline \multirow{17}{*}{ 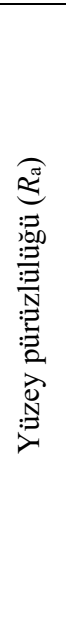 } & Ağaç Türü (A) & 2 & 97.242 & 48.621 & 2397.3387 & $0.0000^{*}$ \\
\hline & Isıl işlem (B) & 2 & 21.327 & 10.664 & 525.7938 & $0.0000 *$ \\
\hline & Etkileşim (AB) & 4 & 24.450 & 6.112 & 301.3859 & $0.0000 *$ \\
\hline & Vernik Çeşidi (C) & 1 & 129.991 & 129.991 & 6409.4024 & $0.0000 *$ \\
\hline & Etkilessim (AC) & 2 & 44.987 & 22.494 & 1109.0855 & $0.0000 *$ \\
\hline & Etkileşim (BC) & 2 & 5.944 & 2.972 & 146.5334 & $0.0000 *$ \\
\hline & Etkileşim (ABC) & 4 & 4.987 & 1.247 & 61.4710 & $0.0000^{*}$ \\
\hline & Yaşlandırma Periyodu (D) & 3 & 15.630 & 5.210 & 256.8813 & $0.0000 *$ \\
\hline & Etkileşim (AD) & 6 & 5.142 & 0.857 & 42.2554 & $0.0000 *$ \\
\hline & Etkilessim (BD) & 6 & 5.206 & 0.868 & 42.7816 & $0.0000 *$ \\
\hline & Etkileşim (ABD) & 12 & 7.826 & 0.652 & 32.1562 & $0.0000 *$ \\
\hline & Etkileşim (CD) & 3 & 3.302 & 1.101 & 54.2670 & $0.0000 *$ \\
\hline & Etkileşim (ACD) & 6 & 1.855 & 0.309 & 15.2421 & $0.0000^{*}$ \\
\hline & Etkileşim (BCD) & 6 & 2.139 & 0.356 & 17.5749 & $0.0000 *$ \\
\hline & Etkileşim (ABCD) & 12 & 6.954 & 0.579 & 28.5723 & $0.0000^{*}$ \\
\hline & Hata & 648 & 13.142 & 0.020 & & \\
\hline & Toplam & 719 & 390.122 & & & \\
\hline \multirow{17}{*}{ 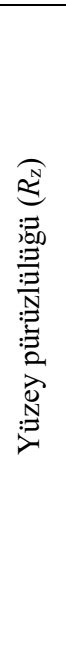 } & Ağaç Türü (A) & 2 & 4541.083 & 2270.542 & 3219.7018 & $0.0000^{*}$ \\
\hline & Isıl işlem (B) & 2 & 436.132 & 218.066 & 309.2250 & $0.0000 *$ \\
\hline & Etkileşim (AB) & 4 & 745.529 & 186.382 & 264.2962 & $0.0000^{*}$ \\
\hline & Vernik Çeşidi (C) & 1 & 4957.334 & 4957.334 & 7029.6609 & $0.0000^{*}$ \\
\hline & Etkileşim (AC) & 2 & 2265.133 & 1132.567 & 1606.0162 & $0.0000^{*}$ \\
\hline & Etkileşim (BC) & 2 & 158.012 & 79.006 & 112.0328 & $0.0000^{*}$ \\
\hline & Etkileşim (ABC) & 4 & 153.600 & 38.400 & 54.4525 & $0.0000 *$ \\
\hline & Yaşlandırma Periyodu (D) & 3 & 546.902 & 182.301 & 258.5084 & $0.0000^{*}$ \\
\hline & Etkileşim (AD) & 6 & 333.118 & 55.520 & 78.7287 & $0.0000^{*}$ \\
\hline & Etkileşim (BD) & 6 & 189.990 & 31.665 & 44.9020 & $0.0000^{*}$ \\
\hline & Etkileşim (ABD) & 12 & 225.207 & 18.767 & 26.6126 & $0.0000^{*}$ \\
\hline & Etkileşim (CD) & 3 & 172.851 & 57.617 & 81.7027 & $0.0000^{*}$ \\
\hline & Etkileşim (ACD) & 6 & 124.568 & 20.761 & 29.4402 & $0.0000^{*}$ \\
\hline & Etkileşim (BCD) & 6 & 54.394 & 9.066 & 12.8554 & $0.0000^{*}$ \\
\hline & Etkileşim (ABCD) & 12 & 200.810 & 16.734 & 23.7295 & $0.0000^{*}$ \\
\hline & Hata & 648 & 456.971 & 0.705 & & \\
\hline & Toplam & 719 & 15561.971 & & & \\
\hline \multirow{17}{*}{ 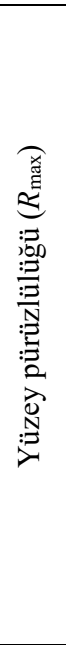 } & Ağaç Türü (A) & 2 & 17867.533 & 8933.766 & 5168.4551 & $0.0000 *$ \\
\hline & Isıl işlem (B) & 2 & 2341.601 & 1170.801 & 677.3437 & $0.0000^{*}$ \\
\hline & Etkileşim (AB) & 4 & 4136.502 & 1034.125 & 598.2730 & $0.0000^{*}$ \\
\hline & Vernik Çeşidi (C) & 1 & 12991.828 & 12991.828 & 7516.1671 & $0.0000^{*}$ \\
\hline & Etkileşim (AC) & 2 & 9885.774 & 4942.887 & 2859.6102 & $0.0000^{*}$ \\
\hline & Etkileşim (BC) & 2 & 1182.314 & 591.157 & 342.0023 & $0.0000^{*}$ \\
\hline & Etkileşim (ABC) & 4 & 1657.320 & 414.330 & 239.7024 & $0.0000^{*}$ \\
\hline & Yaşlandırma Periyodu (D) & 3 & 661.943 & 220.648 & 127.6515 & $0.0000^{*}$ \\
\hline & Etkileşim (AD) & 6 & 522.510 & 87.085 & 50.3813 & $0.0000^{*}$ \\
\hline & Etkileşim (BD) & 6 & 698.824 & 116.471 & 67.3819 & $0.0000^{*}$ \\
\hline & Etkileşim (ABD) & 12 & 1191.351 & 99.279 & 57.4361 & $0.0000^{*}$ \\
\hline & Etkileşim (CD) & 3 & 354.037 & 118.012 & 68.2737 & $0.0000^{*}$ \\
\hline & Etkileşim (ACD) & 6 & 502.873 & 83.812 & 48.4879 & $0.0000^{*}$ \\
\hline & Etkileşim (BCD) & 6 & 282.185 & 47.031 & 27.2087 & $0.0000^{*}$ \\
\hline & Etkileşim (ABCD) & 12 & 988.566 & 82.380 & 47.6596 & $0.0000^{*}$ \\
\hline & Hata & 648 & 1120.080 & 1.729 & & \\
\hline & Toplam & 719 & 56385.241 & & & \\
\hline
\end{tabular}

Yapılan başka bir araştırmada ortamda rutubet varsa yaşlandırmadaki sıcaklık etkisinin termoliz, termolitik ve pirolitik tahribata neden olduğunu, ayrıca yüksek sıcaklıklarda birbiri ile bağ kurarak sertleşmeye başlayan polimerlerde, sıcaklık $32^{\circ} \mathrm{C}$ 'de sabit tutulsa bile bağlarda kopmalar ve 
katman kayıplarının görülebileceği bildirmiştir. (Çakıcier ve Korkut 2009; Feller 1994).

Sögütlü ve Sönmez (2006) tarafindan yapılan bir çalışmada, 144 saatlik hızlandırılmış yaşlandırma süresinden sonra katmanda 1ş1k etkisi ile bozunmanın başladığını ve UV 1şınların etkisiyle yüzey pürüzlülüğünün de $\operatorname{arttığ~}$, en fazla artışın meşe odununda görüldüğü bildirilmiştir.

Çakıcıer (2007) tarafindan yapılan araştırmada, vernik katmanı yüzey pürüzlülügüünde farklı katman kalınlığ uygulamalarının önemli etkisinin olduğu ifade edilmiştir. Özellikle, su bazlı tek bileşenli verniğin iki kat uygulandığı örneklerde, en yüksek yüzey pürüzlülüğü değerleri elde edilirken, yaşlandırma süresi uzadıkça yüzey pürüzlülük değerlerinde artış görüldüğü, 144 saatlik yaşlandırma süresinin sonunda 1şık etkisi ile bozunmanın başladığını belirtilmiştir. Yang vd.
(2001) yaptıkları çalışmada, yaşlandırma işleminin başlangıcında sadece katman parlaklığında hızlı bir azalma görüldügünü, işlemin ileri aşamalarında yüzey geriliminin arttığını, kabarcıklanma oluşumunun gözlendiğini ve daha sonra kilcal çatlaklıkların oluşması ile yüzey pürüzlülüğünün arttığını bildirmişlerdir.

\section{Sonuçlar}

Araştırma sonuçlarına göre, ağaç türü düzeyinde yüzey pürüzlülügü değerleri en yüksek meșede, en düşük sarıçamda tespit edilmiştir. Bu durum, denemelerde kullanılan ağaç türlerinin tekstürleri ve ahşap malzemeye uygulanan isıl işlem sonrasında meydana gelebilecek yüzey değişiklikleri ve anatomik özelliklerdeki farklılaşmalardan kaynaklanmış olabilir.

Tablo 7. Ağaç türü, ısıl işlem, vernik çeşidi ve yaşlandırma periyodu değişkenlerinde yüzey pürüzlülüğü Ra, $R_{\mathrm{z}}$ ve $R_{\max }$ ölçümlerine ait Duncan testleri ve LSD sonuçları.

\begin{tabular}{|c|c|c|c|c|c|}
\hline Test & $\mathrm{Fak}$ & & $X$ & $H G$ & LSD + \\
\hline \multirow{12}{*}{ Yüzey pürüzlülüğü $\left(R_{\mathrm{a}}\right)$} & \multirow{3}{*}{ Ağaç Türü } & Sarıçam & 0.67 & $\mathrm{C}$ & \multirow{3}{*}{0.02535} \\
\hline & & Kayın & 0.78 & $\mathrm{~B}$ & \\
\hline & & Meşe & 1.50 & $\mathrm{~A}^{*}$ & \\
\hline & \multirow{3}{*}{ Isıll İşlem } & $190^{\circ} C^{\prime}$ de 2 Saat & 0.81 & $\mathrm{C}$ & \multirow{3}{*}{0.02535} \\
\hline & & $212^{\circ} \mathrm{C}^{\prime}$ de 1 Saat & 1.22 & $\mathrm{~A}^{*}$ & \\
\hline & & $212^{\circ} \mathrm{C}^{\prime}$ de 2 Saat & 0.91 & $\mathrm{~B}$ & \\
\hline & \multirow{2}{*}{ Vernik Çeşidi } & Tek Bileşenli & 1.41 & $\mathrm{~A}^{*}$ & \multirow[b]{2}{*}{0.02070} \\
\hline & & Çift Bileşenli & 0.56 & $\mathrm{~B}$ & \\
\hline & \multirow{4}{*}{ Yaşlandırma Periyodu } & Kontrol & 0.75 & $\mathrm{D}$ & \multirow{4}{*}{0.02927} \\
\hline & & 144 Saat & 1.14 & $\mathrm{~A}^{*}$ & \\
\hline & & 288 Saat & 1.07 & $\mathrm{~B}$ & \\
\hline & & 432 Saat & 0.96 & $\mathrm{C}$ & \\
\hline \multirow{12}{*}{ Yüzey pürüzlülüğü $\left(R_{\mathrm{z}}\right)$} & \multirow{3}{*}{ Ağaç Türü } & Sarıçam & 3.58 & $\mathrm{C}$ & \multirow{3}{*}{0.1505} \\
\hline & & Kayın & 4.43 & $\mathrm{~B}$ & \\
\hline & & Meşe & 9.28 & $\mathrm{~A}^{*}$ & \\
\hline & \multirow{3}{*}{ Is1l İşlem } & $190^{\circ} C^{\prime}$ de 2 Saat & 5.01 & $\mathrm{C}$ & \multirow{3}{*}{0.1505} \\
\hline & & $212^{\circ} \mathrm{C}^{\prime}$ de 1 Saat & 6.84 & $\mathrm{~A}^{*}$ & \\
\hline & & $212^{\circ} C^{\prime}$ de 2 Saat & 5.45 & $\mathrm{~B}$ & \\
\hline & \multirow{2}{*}{ Vernik Çeşidi } & Tek Bileşenli & 8.39 & $\mathrm{~A}^{*}$ & \multirow{2}{*}{0.1229} \\
\hline & & Çift Bileşenli & 3.14 & $\mathrm{~B}$ & \\
\hline & \multirow{4}{*}{ Yaşlandırma Periyodu } & Kontrol & 4.33 & $\mathrm{C}$ & \multirow{4}{*}{0.1738} \\
\hline & & 144 Saat & 6.49 & $\mathrm{~A}^{*}$ & \\
\hline & & 288 Saat & 6.44 & $\mathrm{~A}$ & \\
\hline & & 432 Saat & 5.80 & $\mathrm{~B}$ & \\
\hline \multirow{12}{*}{ Yüzey pürüzlülüğg̈ $\left(R_{\max }\right)$} & \multirow{3}{*}{ Ağaç Türü } & Sarıçam & 5.37 & $\mathrm{C}$ & \multirow{3}{*}{0.2357} \\
\hline & & Kayın & 6.42 & $\mathrm{~B}$ & \\
\hline & & Meşe & 16.42 & $\mathrm{~A}^{*}$ & \\
\hline & \multirow{3}{*}{ Isıl İşlem } & $190^{\circ} \mathrm{C}^{\prime} \mathrm{de} 2$ Saat & 7.74 & $\mathrm{C}$ & \multirow{3}{*}{0.2357} \\
\hline & & $212^{\circ} \mathrm{C}^{\prime}$ de 1 Saat & 11.91 & $\mathrm{~A}^{*}$ & \\
\hline & & $212^{\circ} \mathrm{C}^{\prime}$ de 2 Saat & 8.56 & $\mathrm{~B}$ & \\
\hline & \multirow{2}{*}{ Vernik Çeşidi } & Tek Bileşenli & 13.65 & $\mathrm{~A}^{*}$ & \multirow{2}{*}{0.1925} \\
\hline & & Çift Bileşenli & 5.16 & $\mathrm{~B}$ & \\
\hline & \multirow{4}{*}{ Yaşlandırma Periyodu } & Kontrol & 7.78 & $\mathrm{C}$ & \multirow{4}{*}{0.2722} \\
\hline & & 144 Saat & 10.25 & $\mathrm{~A}^{*}$ & \\
\hline & & 288 Saat & 9.92 & $\mathrm{~B}$ & \\
\hline & & 432 Saat & 9.65 & $\mathrm{~B}$ & \\
\hline
\end{tabular}


Tablo 8. Ağaç türü - 1sıl işlem - vernik çeşidi - yaşlandırma periyodu dörtlü etkileşimine ait yüzey pürüzlülüğü $\left(R \mathrm{a}, R_{\mathrm{z}}\right.$ ve $\left.R_{\max }\right)$ ölçümlerinin Duncan testi ve LSD değeri sonuçları.

\begin{tabular}{|c|c|c|c|c|c|c|c|c|c|c|c|c|c|c|c|c|}
\hline \multirow[b]{3}{*}{$\stackrel{\overrightarrow{0}}{\oplus}$} & \multirow{3}{*}{ 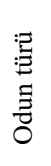 } & \multirow{3}{*}{$\frac{\Xi}{\overrightarrow{0}}$} & \multirow{3}{*}{ 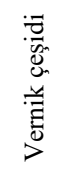 } & \multirow[b]{3}{*}{$\mathrm{N}$} & \multicolumn{12}{|c|}{ Yaşlandırma periyodu } \\
\hline & & & & & \multicolumn{3}{|c|}{ Kontrol } & \multicolumn{3}{|c|}{144 saat } & \multicolumn{3}{|c|}{288 saat } & \multicolumn{3}{|c|}{432 saat } \\
\hline & & & & & $X$ & $S$ & $H G$ & $X$ & $S$ & $H G$ & $X$ & $S$ & $H G$ & $X$ & $S$ & $H G$ \\
\hline \multirow{18}{*}{ 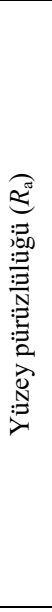 } & & & Tek & 10 & 0.47 & 0.11 & abcdefghi & 0.49 & 0.05 & abcdefg & 0.69 & 0.08 & UVWX & 0.56 & 0.05 & YZabcd \\
\hline & & $\mathrm{IW}_{1}$ & Çift & 10 & 0.24 & 0.02 & $\mathrm{~m}$ & 0.31 & 0.04 & jklm & 0.44 & 0.03 & defghi & 0.41 & 0.05 & fghijk \\
\hline & 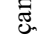 & & Tek & 10 & 0.83 & 0.14 & QRST & 1.32 & 0.17 & JK & 0.95 & 0.09 & OPQ & 0.84 & 0.12 & QRST \\
\hline & $\overline{\bar{E}}$ & $\mathrm{IW}_{2}$ & Çift & 10 & 0.29 & 0.06 & $\mathrm{klm}$ & \begin{tabular}{|l|}
0.75 \\
\end{tabular} & 0.06 & STUV & 0.58 & 0.06 & XYZab & 0.77 & 0.08 & RSTU \\
\hline & & TW & Tek & 10 & 0.72 & 0.10 & TUVW & 1.16 & 0.08 & LM & 1.55 & 0.17 & FG & 0.88 & 0.09 & PQR \\
\hline & & $1 \mathrm{~W}$ & Çift & 10 & 0.68 & 0.10 & UVWXY & \begin{tabular}{|l|l|} 
\\
\end{tabular} & 0.11 & ijklm & 0.54 & 0.07 & Zabcde & 0.25 & 0.02 & $\mathrm{~m}$ \\
\hline & & & Tek & 10 & 0.63 & 0.09 & VWXYZ & 1.08 & 0.08 & $\mathrm{MN}$ & 1.36 & 0.15 & IJK & 1.00 & 0.09 & NOP \\
\hline & & $1 \mathrm{w}_{1}$ & Çift & 10 & 0.40 & 0.05 & fghijkl & 0.74 & 0.09 & TUVW & 0.79 & 0.06 & RSTU & 0.59 & 0.07 & $\mathrm{XYZa}$ \\
\hline & $\equiv$ & & Tek & 10 & 0.84 & 0.13 & QRST & 1.11 & 0.06 & MN & 1.25 & 0.02 & $\mathrm{KL}$ & 1.39 & 0.10 & HIJ \\
\hline & $\ddot{\simeq}$ & $1 \mathrm{~W}_{2}$ & Çift & 10 & 0.28 & 0.07 & $1 \mathrm{~m}$ & 0.40 & 0.05 & fghijkl & 0.45 & 0.04 & cdefghi & 0.62 & 0.14 & WXYZ \\
\hline & & & Tek & 10 & 0.93 & 0.13 & PQ & 1.44 & 0.19 & GHIJ & 0.79 & 0.09 & RSTU & 1.06 & 0.02 & MNO \\
\hline & & $1 \mathrm{w}_{3}$ & Çift & 10 & 0.37 & 0.04 & ghijklm & 0.43 & 0.02 & efghij & 0.36 & 0.03 & hijklm & 0.35 & 0.03 & ijklm \\
\hline & & TW & Tek & 10 & 1.34 & 0.22 & $\mathrm{JK}$ & 2.36 & 0.29 & D & 1.96 & 0.16 & E & 1.50 & 0.14 & FGH \\
\hline & & 101 & Çift & 10 & 0.48 & 0.03 & abcdefgh & 0.57 & 0.02 & XYZabc & 0.63 & 0.03 & VWXYZ & 0.50 & 0.05 & abcdef \\
\hline & 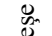 & TW & Tek & 10 & 2.56 & 0.28 & $\mathrm{C}$ & 3.83 & 0.61 & A* & 2.59 & 0.28 & $\mathrm{C}$ & 3.41 & 0.27 & B \\
\hline & $\Sigma$ & $1 \mathrm{w}_{2}$ & Çift & 10 & 0.57 & 0.10 & XYZabc & \begin{tabular}{|l|}
1.49 \\
\end{tabular} & 0.12 & FGHI & 1.14 & 0.10 & LM & 0.94 & 0.13 & OPQ \\
\hline & & & Tek & 10 & 1.59 & 0.24 & $\mathrm{~F}$ & 2.28 & 0.20 & $\mathrm{D}$ & 2.36 & 0.25 & $\mathrm{D}$ & 1.49 & 0.18 & FGHI \\
\hline & & $1 \mathrm{~W}_{3}$ & Çift & 10 & 0.28 & 0.05 & $1 \mathrm{~m}$ & 0.46 & 0.10 & bcdefghi & 0.77 & 0.10 & RSTU & 0.83 & 0.12 & QRST \\
\hline & & TW & Tek & 10 & 2.83 & 0.40 & YZabc & 2.71 & 0.45 & Zabc & 3.83 & 0.40 & TUVW & 3.23 & 0.28 & VWXYZ \\
\hline & & $1 \mathrm{~N} 1$ & Çift & 10 & 1.23 & 0.13 & $\mathrm{~h}$ & 1.56 & 0.22 & efgh & 2.86 & 0.38 & YZabc & 2.44 & 0.24 & abcd \\
\hline & & & Tek & 10 & 4.47 & 0.75 & RST & \begin{tabular}{|l|}
5.62 \\
\end{tabular} & 0.49 & NO & \begin{tabular}{|l|}
5.59 \\
\end{tabular} & 0.98 & NOP & 4.49 & 0.63 & RST \\
\hline & $\overline{\bar{E}}$ & $1 \mathrm{w}_{2}$ & Çift & 10 & 1.40 & 0.44 & $\mathrm{~h}$ & 3.11 & 0.37 & WXYZa & 2.82 & 0.43 & YZabc & 3.14 & 0.63 & WXYZa \\
\hline & & & Tek & 10 & 4.09 & 0.52 & STU & 6.55 & 1.03 & KLM & 8.23 & 1.04 & I & 5.34 & 0.58 & OPQ \\
\hline$\sigma^{N}$ & & $1 \mathrm{~W}_{3}$ & Çift & 10 & 3.84 & 0.43 & TUVW & 1.62 & 0.31 & efgh & 3.55 & 0.64 & UVWXY & 1.44 & 0.18 & gh \\
\hline 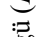 & & $\mathrm{TV}$ & Tek & 10 & 4.16 & 0.58 & RSTU & 5.83 & 0.29 & MNO & 6.93 & 0.89 & $\mathrm{KL}$ & 5.68 & 0.56 & $\mathrm{NO}$ \\
\hline 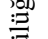 & & $1 \mathrm{~W} /$ & Çift & 10 & 2.71 & 0.36 & Zabc & 4.00 & 0.44 & $\mathrm{TU}$ & 4.24 & 0.29 & RSTU & 3.76 & 0.46 & TUVW \\
\hline : & $\equiv$ & $\mathrm{TW}_{2}$ & Tek & 10 & 4.82 & 0.68 & QRS & 6.18 & 0.41 & MN & 6.92 & 0.38 & $\mathrm{KL}$ & 8.00 & 0.75 & I \\
\hline 吾 & $\check{\simeq}$ & 1.2 & Çift & 10 & 1.34 & 0.25 & $\mathrm{~h}$ & 2.16 & 0.36 & cdefg & 2.60 & 0.47 & Zabc & 3.63 & 0.44 & UVWX \\
\hline$\stackrel{2}{2}$ & & $\mathrm{TW}_{3}$ & Tek & 10 & 4.88 & 0.50 & $\mathrm{PQR}$ & 7.91 & 1.57 & I & 4.80 & 0.32 & QRS & \begin{tabular}{|l|l|}
6.11 \\
\end{tabular} & 0.63 & MN \\
\hline$\stackrel{\mathscr{N}}{\cong}$ & & $1 \mathrm{~W}_{3}$ & Çift & 10 & 2.99 & 0.53 & XYZab & 2.44 & 0.23 & abcd & 2.20 & 0.22 & cdef & 1.78 & 0.21 & defgh \\
\hline & & TU & Tek & 10 & 9.12 & 1.78 & $\mathrm{H}$ & 15.47 & 2.01 & $\mathrm{D}$ & 14.31 & 2.33 & E & 10.90 & 1.16 & $\mathrm{G}$ \\
\hline & & $1 \mathrm{w}_{1}$ & Çift & 10 & 2.73 & 0.40 & Zabc & 3.00 & 0.44 & XYZab & 3.88 & 0.53 & TUV & 2.62 & 0.46 & Zabc \\
\hline & $\underbrace{}_{s}$ & TW & Tek & 10 & 12.60 & 1.24 & $\mathrm{~F}$ & 23.71 & 1.21 & $\mathrm{~A}^{*}$ & 16.76 & 1.83 & $\mathrm{C}$ & 21.46 & 1.53 & B \\
\hline & $\Sigma$ & 102 & Çift & 10 & 3.02 & 0.50 & XYZab & 7.71 & 0.60 & $\mathrm{IJ}$ & 7.13 & 0.84 & JK & 5.72 & 0.45 & NO \\
\hline & & & Tek & 10 & 10.26 & 1.31 & $\mathrm{G}$ & 14.90 & 1.63 & $\mathrm{DE}$ & 13.06 & 1.42 & $\mathrm{~F}$ & 10.31 & 0.98 & $\mathrm{G}$ \\
\hline & & $1 \mathrm{~W}_{3}$ & Çift & 10 & 1.51 & 0.28 & fgh & 2.29 & 0.33 & bcde & 4.39 & 0.57 & RST & 6.27 & 0.61 & LMN \\
\hline & & $\mathrm{T}$ & Tek & 10 & 4.62 & 0.68 & XYZabc & 4.33 & 0.64 & YZabcde & 5.20 & 1.15 & VWXYZa & 4.19 & 0.55 & Zabcde \\
\hline & & $1 \mathrm{~W}_{1}$ & Çift & 10 & 1.83 & 0.49 & $j$ & 2.38 & 0.25 & hij & \begin{tabular}{|l|l|}
5.48 \\
\end{tabular} & 0.83 & TUVWXY & 4.28 & 0.46 & Zabcde \\
\hline & 局 & TW & Tek & 10 & 6.14 & 0.53 & RSTUV & 7.51 & 1.02 & OPQ & 7.48 & 1.61 & OPQ & 6.56 & 1.40 & QRST \\
\hline & $\bar{E}$ & $1 \mathrm{w}_{2}$ & Çift & 10 & 2.13 & 0.43 & $\mathrm{ij}$ & 4.32 & 0.49 & Zabcde & 4.40 & 0.71 & YZabcde & 5.25 & 1.34 & UVWXYZ \\
\hline & & $\mathrm{TW}_{3}$ & Tek & 10 & 6.14 & 0.40 & RSTUV & 9.11 & 0.84 & KLM & 11.67 & 0.93 & $\mathrm{HI}$ & 7.86 & 1.14 & $\mathrm{OP}$ \\
\hline 象 & & $1 \mathrm{~W}_{3}$ & Çift & 10 & 6.39 & 1.02 & QRSTU & 3.00 & 0.58 & fghi & 6.10 & 1.26 & RSTUV & 2.47 & 0.32 & ghij \\
\hline$:=$ & & $\mathrm{TW}_{1}$ & Tek & 10 & 5.91 & 1.12 & RSTUVW & 7.99 & 1.12 & MNOP & 9.53 & 1.20 & KL & 7.92 & 1.33 & NOP \\
\hline 灌 & & & Çift & 10 & 4.16 & 0.99 & Zabcde & 5.67 & 1.46 & STUVWX & 6.99 & 0.97 & $\mathrm{PQR}$ & 4.93 & 1.60 & WXYZa \\
\hline $\mathrm{Z}_{\mathrm{N}}$ & ह & $\mathrm{TW}_{2}$ & Tek & 10 & 7.90 & 1.76 & $\mathrm{OP}$ & 8.06 & 0.80 & MNOP & 9.06 & 1.10 & KLMN & 12.01 & 2.09 & $\mathrm{HI}$ \\
\hline 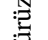 & 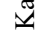 & $1 \mathrm{w}_{2}$ & Çift & 10 & 1.86 & 0.49 & ij & 3.65 & 1.24 & bcdef & 4.53 & 0.60 & XYZabcd & 6.20 & 1.40 & RSTUV \\
\hline 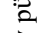 & & TW & Tek & 10 & 6.69 & 1.53 & QRS & 9.70 & 1.35 & $\mathrm{~K}$ & 6.57 & 1.62 & QRST & 8.48 & 2.13 & LMNO \\
\hline बे & & 103 & Çift & 10 & 4.78 & 1.26 & WXYZab & 4.58 & 0.74 & XYZabc & 3.36 & 0.89 & efgh & 3.54 & 0.64 & cdefg \\
\hline : & & TW & Tek & 10 & 12.41 & 1.37 & $\mathrm{H}$ & 26.75 & 1.52 & $\mathrm{C}$ & 22.40 & 1.71 & $\mathrm{D}$ & 20.18 & 2.21 & E \\
\hline & & $1 \mathrm{~N} 1$ & Çift & 10 & 4.19 & 0.59 & Zabcde & 4.76 & 0.72 & WXYZab & 6.25 & 0.54 & RSTUV & 3.39 & 0.75 & defgh \\
\hline & $\underbrace{}_{\infty}$ & TW & Tek & 10 & 37.79 & 2.84 & B & 48.14 & 4.71 & $\mathrm{~A}^{*}$ & 26.60 & 2.69 & $\mathrm{C}$ & 38.31 & 1.59 & B \\
\hline & $\Sigma$ & $1 \mathrm{~W}_{2}$ & Çift & 10 & 5.14 & 0.86 & VWXYZa & 11.72 & 0.99 & $\mathrm{HI}$ & 10.14 & 0.58 & $\mathrm{JK}$ & 10.93 & 1.43 & $\mathrm{IJ}$ \\
\hline & & TV & Tek & 10 & 10.93 & 0.59 & IJ & 18.87 & 0.88 & FG & 21.43 & 1.38 & $\mathrm{D}$ & 17.94 & 0.96 & $\mathrm{G}$ \\
\hline & & 103 & Çift & 10 & 2.05 & 0.50 & ij & 4.05 & 0.71 & abcdef & 11.38 & 1.43 & $\mathrm{HI}$ & 9.31 & 0.82 & KL \\
\hline & & & & & & & & & 0. & & & & & & & \\
\hline
\end{tabular}

Is1l işlem düzeyinde, yüzey pürüzlülüğü değerleri, en yüksek $212^{\circ} \mathrm{C}^{\prime}$ de 1 saatte, en düşük $190^{\circ} \mathrm{C}$ 'de 2 saatte elde edilmiştir. Buna göre, düşük ve orta derecede uygulanan isıl işlem sıcaklığının yüzey pürüzlülüğü değerlerini arttırıcı, yüksek derecede uygulanan 1 sıl işlem sıcaklığının ise azaltıcı etkide bulunduğu söylenebilir. 
$\mathrm{Bu}$ araştırmada 1 sil işlem süresi arttıça pürüzlülüğün arttığ1 tespit edilmiştir. Bunun da sebebi olarak ThermoWood yöntemine göre yapılan ısıl işlem uygulamasının etüv ortamına göre yapılan çalışmalardan daha homojen bir uygulama olduğu, ağaç malzemenin iç bölgesindeki daha derin kısımlara kadar nüfuz edebildiği ve ayrıca liflerin ThermoWood metodunda odunun yanmasinı engelleyen koruyucu buharın yüzey yapısını değiştirmiş olmasından kaynaklandığı söylenebilir.

Vernik çeşidi düzeyinde yüzey pürüzlülüğü değerleri en yüksek tek bileşenli vernikte, en düşük çift bileşenli vernikte elde edilmiş̧ir. Bu durumda, ağaç malzemenin boşluklarını tam olarak dolduramayan tek bileşenli vernik katmanlarının 1sıl işlem ve yaşlandırma uygulamalarının da etkisiyle en fazla pürüzlülük değeri verdiği söylenebilir. Araştırmada kullanılan çift bileşenli vernik formülasyonunda bulunan alifatik poliüretan reçinenin izosiyanat (sertleştirici) ile reaksiyonu sonucu edilen iki bileşenli verniğin katmanındaki yüzey geriliminin az olacağ 1 için pürüzlülükte azalmaya yol açmış olabileceği söylenebilir.

Yaşlandırma periyodu düzeyinde yüzey pürüzlülüğü değerleri en yüksek 144 saatlik UV yaşlandırma örneklerinde, en düşük kontrol örneklerinde tespit edilmiş, bütün yaşlandırma periyotları arasında sadece $R_{\mathrm{a}}$ değerlerinde $\% 95$ güven aralığı düzeyinde istatistiksel olarak anlamlı farklılık gözlemlenmiştir. Buna göre, gerek 1sıl işlem gerekse yaşlandırma işlemlerinin birlikte uygulandığı su çözücülü vernik katmanlarında uzun süreli yaşlandırma işlemlerinin ilk aşamalarında pürüzlülük değerinin arttığ 1 , daha sonraki aşamalarda ise azaldığ 1 tespit edilmiştir.

\section{Teşekkür}

Bu çalışma "Isıl işlem görmüş (ThermoWood) bazı ağaç türlerinde kullanılan su-bazlı vernik katmanlarının hızlandırılmış UV yaşlandırma etkisine karşı direncinin belirlenmesi" başlıklı doktora tezinden üretilmiş ve Düzce Üniversitesi BAP-2012.02.HD.078 numaral1 Bilimsel Araştırma Projesiyle desteklenmiştir.

\section{Kaynaklar}

Altınok, M., Perçin, O., Doruk, Ş., 2010. Is11 işlemin (Thermo-Process) ağaç malzemenin teknolojik özelliklerine etkisinin incelenmesi, Dumlupınar Üniversitesi, Fen Bilimleri Enstitüsü Dergisi, 23, 71-84.
Anonymous, 2003. ThermoWood Handbook, Finnish ThermoWood Association, Helsinki-Finland.

ASTM D 1644-01, 2006. Standard Test Methods for Nonvolatile Content of Varnishes. American Society for Testing and Materials, West Conshohocken, Pennsylvania, USA.

ASTM D 6132, 2008. Standard test method for nondestructive measurement of dry film thickness of applied organic coatings using an ultrasonic gage.

ASTM G 154-06, 2006. Standard practice for operating fluorescent light apparatus for UV exposure of nonmetallic materials, ASTM, USA, 2-8.

Ayata, Ü., 2014. Isı1 işlem görmüş (ThermoWood) bazı ağaç türlerinde kullanılan su-bazlı vernik katmanlarının hızlandırılmış UV yaşlandırma etkisine karşı direncinin belirlenmesi, Doktora Tezi, Düzce Üniversitesi, Fen Bilimleri Enstitüsü, Orman Endüstri Mühendisliği Anabilim Dalı, Düzce.

Aytin, A., 2013. Yabani kiraz (Cerasus avium (1.) Monench) odununun fiziksel, mekanik ve teknolojik özellikleri üzerine yüksek sıcaklık uygulamasının etkisi, Doktora Tezi, Düzce Üniversitesi, Düzce.

Aytin, A., Korkut, S., ve Çakıcıer, N., 2015. Yabani kiraz odununda bazı yüzey karakteristikleri üzerine ThermoWood ${ }^{\circledR}$ yöntemi ile 1sıl işlemin etkisi, Selçuk-Teknik Dergisi, Özel Say1-1 (UMK-2015), 539-554.

Bakar, B.F.A., Hiziroğlu, S., Tahir, P.M., 2013. Properties of some thermally modifies wood species, Materials and Design, 43, 348-355.

Bozkurt, Y., Göker, Y., Erdin N., 1993. Emprenye Tekniği, İ.Ü. Orman Fakültesi Yayınları, İstanbul, 3779 (425), 125 ve 429.

Çakıcıer, N., 2007. Ağaç malzeme yüzey işlemi katmanlarında yaşlanma sonucu belirlenen değişiklikler, Doktora Tezi, İstanbul Üniversitesi İstanbul, İstanbul.

Çakıcıer, N., ve Korkut, D.S., 2009. Ahşap yüzeylere uygulanan kaplama katmanlarında yaşlandırma testleri, Düzce Üniversitesi, Ormanc1lık Dergisi, 5 (1) 7590. 
Feller, R.L., 1994. Accelerated Aging, Photochemical and Thermal Aspects, Printed in the United States of America.

ISO 4287, 1997. Geometrical product specifications surface texture profile method terms, definitions and surface texture parameters, International Standart Organization.

Kazan, B., 2009. Su bazlı vernik uygulanmış yüzey üzerindeki 1sıl işlemin etkileri, Dumlupınar Üniversitesi, Fen Bilimleri Enstitüsü, Mobilya ve Dekorasyon Eğitimi Anabilim Dalı, Yüksek Lisans Tezi, Dumlupınar.

Kesik, H.İ., Vurdu, H., Çağatay, K., Özkan, O.E., Öncel, M., 2015. Yağl1 Isıl işlem görmüş sarıçam odununda koruyucu katmanların yapışma ve sertlik özellikleri, Kastamonu Üni., Orman Fakültesi Dergisi, 15 (2) 261266.

Korkut S., and Budakci M., 2010. The effects of high-temperature heat-treatment on physical properties and surface roughness of Rowan (Sorbus aucuparia L.) wood, Wood Research, 55 (1) 67-78.

Korkut, S., 1999. Kereste üretiminde yüzey kalitesinin iyileştirilmesi üzerine araştırmalar, Yüksek Lisans Tezi, İstanbul Üniversitesi, İstanbul.

Özcan, S., Özçiftçi, A., Hiziroğl1, S., Toker, H., 2012. Effects of heat treatment and surface roughness on bonding strength, Construction and Building Materials, 33, 713.

Portable Surface Roughness Tester Surftest Sj-301, 1998. yüzey pürüzlülüğü ölçüm cihazı kullanım kılavuzu.

Richter, K., Fest, W.C., Knaebe, M.T., 1995. The effect of surface roughness on the performence of finishes, Forest Products Journal, 45 (7) 91-97.
Söğütlü, C., ve Sönmez, A., 2006. Değişik koruyucular ile işlem görmüş bazı yerli ağaçlarda UV ışınlarının renk değiştirici etkisi, Gazi Üniversitesi Müh. Mimarlık Fak. Dergisi, 21 (1) 151-159.

Sönmez, A., ve Söğütlü, C., 2009. Biçme İşleminde Kesiş Yönü ve Daire Testere Diş Sayısının Ağaç Malzeme Yüzey Pürüzlülüğüne Etkisi, Politeknik Dergisi, 12 (1) 55-60.

Temiz, A., 2005. Benzetilmiş dış hava koşullarının emprenyeli ağaç malzemeye etkileri, Doktora tezi, Karadeniz Teknik Üniversitesi, Fen Bilimleri Enstitüsü, Orman Endüstri Mühendisliği Anabilim Dalı, Trabzon.

TS 5723, 1988. Ahşap koruma-emprenye maddesi nüfuz derinliğinin tayini, Türk Standartları Enstitüsü, Ankara.

TS 642, 1997. Kondisyonlama ve / veya Deney İçin Standart Atmosferler-Özellikler, Türk Standartları Enstitüsü, Ankara.

TS EN 351-1, 2010. Ahşap ve ahşap esaslı mamullerin dayanıklılığı-emprenye edilmiş masif ahşap-Bölüm 1: Emprenye maddesinin nüfuz derinliği ve tutulma miktarının sınıflandırılması. T.S.E., Ankara.

Unsal, O., and Ayrilmis, N., 2005. Variations in compression strength and surface roughness of heat-treated Turkish river red rum (Eucalyptus camaldulensis) wood, Journal of Wood Science, 51, 405-409.

Yang, X.F., Vang, C., Tallman, D.E., Bierwagen, G.P., Croll, S.G., and Rohlik, S., 2001. Weathering degradation of a polyurethane coating, polymer degradation and stability, 74, 341-351. 